\title{
Pengaruh Kompleksitas Tugas Terhadap Kualitas Audit Dengan Disfungsional Auditor Sebagai Variabel Moderasi
}

\author{
Fitria Magdalena Suprapto ${ }^{*}$, Wawan Cahyo Nugroho ${ }^{2}$ \\ 'Universitas Islam Kediri, 'Sekolah Tinggi Ilmu Ekonomi Indonesia Surabaya \\ 'fitria.magdalena@uniska-kediri.ac.id, ${ }^{2}$ wawancahyonugroho@stiesia.ac.id \\ ${ }^{*}$ Penulis korespondensi
}

\begin{abstract}
The auditor is the most important part of the assessor component of an organization's financial statements. People who need financial information as a basis for making decisions expect the independence of public accountants in assessing financial statements so that in order to maintain reputation, auditors are always required to be careful in maintaining audit quality. This study aims to examine the effect of task complexity on audit quality with auditor dysfunctionality as a moderating variable. The research sample used auditors who work in KAP located in Surabaya with the sampling technique using purposive sampling method. The source of research is the primary which comes from the collection of survey on respondents to obtain individual opinion. There are 66 questionnaires that meet the criteria to be sampled. Hypothesis testing uses linear regression and moderated regression analysis. The results showed that task complexity had an effect on audit quality. Dysfunctional auditors are not able to moderate the complexity of the task on audit quality.
\end{abstract}

Keywords: Task complexity, audit quality, auditor dysfunctionality

\begin{abstract}
Abstrak
Auditor merupakan bagian terpenting dari komponen penilai laporan keuangan suatu organisasi. Masyarakat yang membutuhkan informasi keuangan sebagai dasar dalam mengambil keputusan mengharapkan keindependensian akuntan publik dalam menilai laporan keuangan sehingga demi menjaga reputasi, auditor selalu dituntut untuk berhati-hati dalam menjaga kualitas audit. Penelitian ini bertujuan untuk meneliti pengaruh kompleksitas tugas terhadap kualitas audit dengan disfungsional auditor sebagai variabel moderasi. Sampel penelitian menggunakan auditor yang bekerja di KAP yang berlokasi di Surabaya dengan teknik pengambilan sampel menggunakan metode purposive sampling. Sumber data penelitian adalah primer yang berasal dari pengumpulan data survei terhadap responden untuk mendapatkan data opini individu. Terdapat 66 kuesioner yang memenuhi kriteria untuk dijadikan sampel. Pengujian hipotesis menggunakan regresi linear dan moderated regression analysis. Hasil penelitian menunjukkan kompleksitas tugas berpengaruh terhadap kualitas audit. Disfungsional auditor tidak mampu memoderasi kompleksitas tugas terhadap kualitas audit.
\end{abstract}

Kata Kunci: Kompleksitas tugas, kualitas audit, dan disfungsional auditor 


\section{PENDAHULUAN}

Kantor Akuntan Publik adalah suatu organisasi penyedia assurance services yang dibutuhkan perusahaan untuk menilai tanggung jawab pihak manajemen atas laporan keuangan yang telah disajikan. Melalui serangkaian proses audit yang sistematis, para akuntan publik kemudian mengevaluasi bukti-bukti guna memperoleh penilaian bahwa terdapat tingkat kesamaan antara informasi keuangan dengan ukuran atau kriteria yang telah ditetapkan. Para auditor dalam menjalankan tugasnya diwajibkan berpedoman pada standar yang berlaku yakni standar umum, standar pekerjaan lapangan, dan standar pelaporan. Hal ini seperti yang tertuang dalam peraturan yang telah ditetapkan dan disahkan oleh Institut Akuntan Publik Indonesia (IAPI) yang terdiri atas sepuluh standar dan dirinci dalam bentuk Standar Perikatan Audit (SPA). Jika segenap pelaku profesi akuntan publik menjalankannya maka kualitas hasil kerja akan selalu terjaga.

Auditor merupakan salah satu profesi yang menantang dikarenakan sifat pekerjaannya yang sensitif sebagai bagian terpenting dari komponen penilai laporan keuangan suatu organisasi. Kantor Akuntan Publik yang diisi oleh tenaga profesional di bidang akuntansi selalu memperhatikan penilaian dari masyarakat selaku pemangku kepentingan demi menjaga keberlangsungan usahanya. Masyarakat yang membutuhkan informasi keuangan sebagai dasar dalam mengambil keputusan mengharapkan independensi akuntan publik dalam menilai laporan keuangan yang disajikan oleh manajemen perusahaan. Sehingga demi menjaga reputasi, profesi akuntan publik selalu dituntut untuk berhati-hati dalam menjaga kualitas.

Audit yang berkualitas diharapkan mampu menambah kredibilitas laporan keuangan karena prosedur audit yang sesuai dapat mengurangi risiko kesalahan (Risma, 2019). Profesi auditor dituntut untuk menjaga nama profesi karena kesalahan yang dilakukan saat memberikan pelayanan jasa pada klien akan sangat berpengaruh terhadap reputasi profesi. Meskipun telah menyadari arti penting kepercayaan publik, namun kasus yang melibatkan auditor saat bertugas tetap saja marak terjadi, seperti kasus yang terjadi pada Kantor Akuntan Publik mitra Ernst \& Young (EY) di Indonesia, yakni KAP Purwantono, Suherman \& Surja. Claudius B. Modesti selaku Badan Pengawas Kantor Akuntan Publik AS (Public Company Accounting Oversight Board / PCAOB) pada tahun 2017 menyatakan bahwa KAP harus membayar denda senilai US\$ 1 juta (sekitar Rp 13,3 miliar) kepada regulator Amerika Serikat sebagai akibat kegagalan dan ketergesaan mereka dalam memberikan opini pada laporan keuangan klien yang tidak didasarkan atas bukti yang memadai. Mengingat dampak yang ditimbulkan, maka sangat penting untuk meneliti pengaruh kompleksitas pekerjaan yang dihadapi oleh auditor saat menyelesaikan tugas terhadap kualitas audit dengan diperkuat oleh perilaku disfungsional. Studi empiris dilakukan pada auditor yang bekerja pada KAP di Surabaya dikarenakan berdasarkan data IAPI yang diakses pada tahun 2020, Jawa Timur memiliki jumlah KAP yang banyak (www.iapi.or.id).

Bobot pekerjaan yang diberikan dengan waktu penyelesaian yang singkat mendorong auditor untuk mengorbankan waktu pribadi atau di luar jam kerja untuk menyelesaikan 
tugas, membatasi pengumpulan bukti yang seharusnya dikumpukan, dan melakukan penghentian dini terhadap prosedur audit (Rohman, 2018). Seorang auditor dapat berada pada tingkat stress yang tinggi karena kompleksitas tugas yang dihadapi disertai dengan waktu pengerjaan yang singkat dan di bawah tekanan yang tinggi. Kompleksitas tugas mencakup pemahaman auditor terhadap operasi bisnis klien (Wood, 1986). Semakin auditor tidak memahami operasi bisnis klien dengan baik, akan berdampak pada kualitas audit jika waktu pengerjaan yang diberikan sangat singkat.

Sikap etis dan profesional wajib ada dalam setiap jiwa auditor dalam melaksanakan tugasnya untuk menghindari terjadinya penyimpangan perilaku auditor (Sanjaya \& Suputra, 2019). Sikap auditor saat memperoleh informasi audit yang didapat oleh auditor selama melakukan proses audit merupakan hal penting yang akan mempengaruhi hasil audit. Perilaku auditor dalam pelaksanaan program audit merupakan salah satu poin penting untuk menemukan kesalahan dalam laporan keuangan yang diaudit (De Angelio, 1981). Apabila auditor menyikapi setiap informasi audit secara bijak, maka kualitas audit dapat tercapai namun sebaliknya jika perilaku para auditor saat menjalankan program audit cenderung menurunkan kualitas audit secara langsung maupun tak langsung maka perilaku ini disebut perilaku disfungsional (Kelley \& Margheim, 1990).

Perilaku disfungsional yang menyimpang dari standar audit memiliki tanggung jawab yang lebih rendah dalam menyelesaikan tugas. Bentuk perilaku disfungsional audit antara lain penghentian prosedur audit secara tiba-tiba, penggantian tahap audit, dan penyingkatan waktu pengerjaan dari waktu yang diperlukan (Kelley \& Margheim, 1990). Penelitian ini menjadikan perilaku disfungsional auditor sebagai variabel moderasi saat auditor menghadapi kompleksitas tugas terhadap kualitas audit.

Kompleksitas tugas menunjukkan kerumitan atau persepsi tingkat kesulitan karena keterbatasan kemampuan yang dimiliki seseorang dalam menyelesaikan suatu tugas (Dewi \& Wirasedana, 2015). Pekerjaan auditor sering dikaitkan dengan beban kerja yang tidak sedikit dikarenakan tugas yang rumit dan beragam. Namun, tingkat kerumitan ini tidak selalu bermakna negatif, hal ini dapat menjadi positif jika dengan kesulitan yang dihadapi seseorang menjadi lebih termotivasi untuk bekerja lebih keras. Tentunya hal ini bergantung pada respon tiap individu, jika auditor memiliki jiwa yang tangguh dan rasa keingintahuan yang tinggi, akan menjadikan bekerja di bawah tekanan merupakan suatu tantangan yang harus ditaklukkan guna menambah wawasan dan pengalaman baru (Rohman, 2018).

$\mathbf{H}_{\mathbf{1}}$ : Kompleksitas tugas berpengaruh terhadap kualitas audit

Disfungsional auditor adalah perilaku yang dilakukan selama proses pelaksanaan program audit yang dapat mereduksi kualitas audit (Donnely, Jeffrey, \& David, 2003). Akibat buruk dari tindakan disfungsional auditor adalah hasil audit akan cenderung kurang berkualitas sehingga menyesatkan pengguna laporan keuangan. Perilaku menyimpang dari alur dan proses audit tersebut sangat membahayakan pihak berkepentingan dalam 
mengambil keputusan karena hasil audit tidak mampu menjawab adanya salah saji yang disengaja atau human error saat mengumpulkan bukti terkait.

$\mathbf{H}_{2}$ : Disfungsional auditor memoderasi kompleksitas tugas terhadap kualitas audit

\section{METODE}

Berdasarkan pada fenomena yang terjadi, pendekatan penelitian ini menggunakan kuantitatif dengan sumber data primer yang berasal dari pengumpulan data survei terhadap responden untuk mendapatkan data opini individu (Sugiyono, 2011). Angket atau kuisioner yang disebarkan menggunakan skala likert 1 sampai dengan 5 yang berhubungan dengan pernyataan sikap seseorang atas keadaan tertentu. Teknik analisis data menggunakan regresi linear dan moderated regression analysis dengan bantuan SPSS untuk mengetahui pengaruh kompleksitas tugas terhadap kualitas audit yang dihasilkan yang dimoderasi oleh disfungsional auditor.

Populasi penelitian adalah auditor yang bekerja di KAP yang berlokasi di Surabaya. Teknik pengambilan sampel menggunakan metode purposive sampling, yaitu dengan mempertimbangkan beberapa kriteria tertentu: 1). Auditor yang memiliki pengalaman bekerja pada KAP di Surabaya selama minimal satu tahun; dan 2). Auditor pernah ditugaskan dalam kerja lapangan dan telah menyelesaikan satu tugas klien. Dalam penelitian ini terdapat 66 kuesioner yang memenuhi kriteria untuk dijadikan sampel.

Metode analisis yang digunakan pada penelitian ini adalah regresi linear (model 1) untuk $\mathrm{H}_{1}$ dan MRA (model 2) untuk $\mathrm{H}_{2}$. Variabel independen yang diteliti yaitu kompleksitas tugas sedangkan variabel dependennya adalah kualitas audit dan ditambah dengan variabel moderasi yaitu disfungsional auditor. Model regresi untuk menguji hipotesis adalah sebagai berikut:

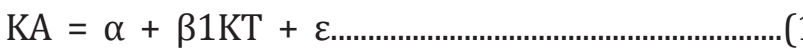

$$
\begin{aligned}
& \mathrm{KA}=\alpha+\beta 1 \mathrm{KT}+\beta 2 \mathrm{DA}+\beta 3 \mathrm{KTDA}+\varepsilon .
\end{aligned}
$$

Keterangan:

$$
\begin{array}{ll}
\mathrm{KA} & =\text { Kualitas Audit } \\
\alpha & =\text { Bilangan konstanta } \\
\beta & =\text { Koefisien arah persamaan penelitian } \\
\mathrm{KT} & =\text { Kompleksitas Tugas } \\
\mathrm{DA} & =\text { Disfungsional Auditor } \\
\varepsilon \quad & =\text { Error }
\end{array}
$$

\section{HASIL DAN PEMBAHASAN}

Responden dalam penelitian ini adalah auditor yang bekerja di KAP yang berlokasi di Surabaya. Dari 100 kuesioner yang disebar, hanya 66 yang berhasil kembali dan memenuhi kriteria untuk dijadikan sebagai data penelitian. Sehingga, tingkat pengembalian kuesioner yang dapat diolah sebanyak 66\% dari keseluruhan yang disebar oleh peneliti. 
Berdasarkan karakteristik demografi responden, sebagian besar berjenis kelamin perempuan sebanyak 36 orang (55\%) dan sisanya sebesar 30 orang (45\%) berjenis kelamin laki-laki. Sebagian besar responden berusia kurang dari 30 tahun dengan persentase sebesar 94\%. Mayoritas responden berpendidikan terakhir S1 dengan jumlah 52 orang atau sebesar 79\% dan sisanya berpendidikan terakhir Diploma dan S2. Rata-rata responden memiliki pengalaman kerja kurang dari 5 tahun sebanyak 57 orang (85\%). Mayoritas memiliki jabatan junior auditor sebanyak 47 orang (71\%), senior auditor sebesar 12 orang (18\%), dan supervisor sebanyak 7 orang (11\%).

\section{Hasil Uji Validitas dan Reliabilitas}

Hasil uji validitas dan reliabilitas disajikan pada tabel 1 dan 2 berikut:

Tabel 1. Hasil Uji Validitas

\begin{tabular}{lccc}
\hline Variabel & Kode Indikator & Pearson Correlation & Keterangan \\
\hline Kompleksitas Tugas & KT1 & 0,884 & Valid \\
& KT2 & 0,838 & Valid \\
& KT3 & 0,832 & Valid \\
Kisfungsional Auditor & KT4 & 0,874 & Valid \\
& DA1 & 0,334 & Valid \\
& DA2 & 0,852 & Valid \\
DA3 & 0,821 & Valid \\
& DA4 & 0,761 & Valid \\
& KA1 & 0,757 & Valid \\
& KA2 & 0,576 & Valid \\
& KA3 & 0,748 & Valid \\
& KA4 & 0,662 & Valid
\end{tabular}

Sumber: Data Penelitian, 2020

Tabel 2. Hasil Uji Realibilitas

\begin{tabular}{lcc}
\hline \multicolumn{1}{c}{ Variabel } & Cronbach's Alpha & Keterangan \\
\hline Kompleksitas Tugas & 0,877 & Reliabel \\
Disfungsional Auditor & 0,656 & Reliabel \\
Kualitas Audit & 0,602 & Reliabel \\
\hline
\end{tabular}

Sumber: Data Penelitian, 2020 
Data pada tabel 1 menunjukkan nilai pearson correlation seluruh indikator dari variabel yang diteliti. Dapat diketahui bahwa semua indikator nilai pearson correlation-nya di atas 0,3 . Hal ini menunjukkan bahwa indikator penelitian tersebut valid atau telah memenuhi syarat uji validitas. Sedangkan, data pada tabel 2 menunjukkan nilai cronbach's alpha dari variabel yang digunakan dalam penelitian ini, yaitu kompleksitas tugas, disfungsional auditor, dan kualitas auditor. Variabel-variabel tersebut memiliki nilai koefisien cronbach's alpha di atas 0,6 sehingga dinyatakan reliabel.

\section{Hasil Uji Asumsi Klasik}

\section{Uji Normalitas}

Dalam penelitian ini, untuk menguji variabel berdistribusi normal atau tidak menggunakan sebaran data (titik) pada sumbu diagonal dari grafik atau histogram dari residualnya. Apabila sebaran data (titik) disekitar garis diagonalnya atau mengikuti arah garis diagonalnya maka model regresi dikatakan normal. Pada Gambar 1 menunjukkan pola grafik histogram model 1 yang berdistribusi normal. Sementara itu, Gambar 2 menunjukkan sebaran titik yang mengikuti arah garis atau disekitar diagonalnya, maka model 2 regresi pada penelitian dikatakan terdistribusi secara normal.

\section{Gambar 1 Hasil Uji Normalitas Model 1}

\section{Normal P-P Plot of Regression Standardized Residual}

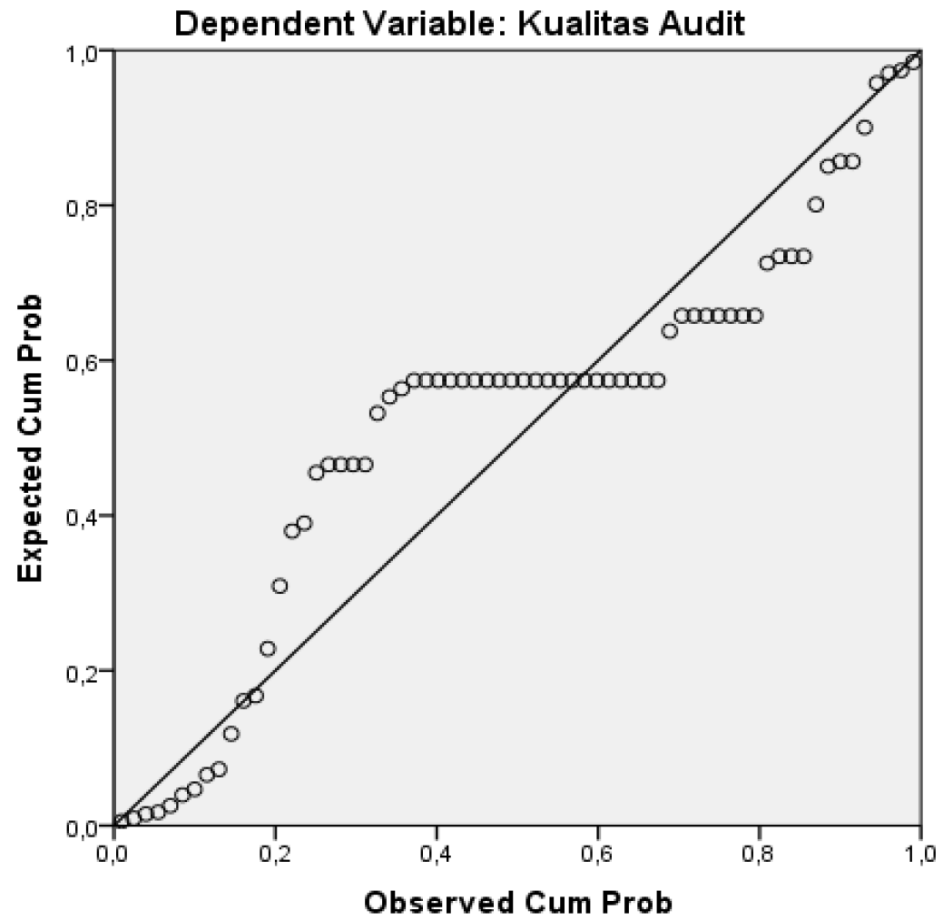

Sumber: Data Penelitian, 2020 


\section{Gambar 2 Hasil Uji Normalitas Model 2}

Normal P-P Plot of Regression Standardized Residual

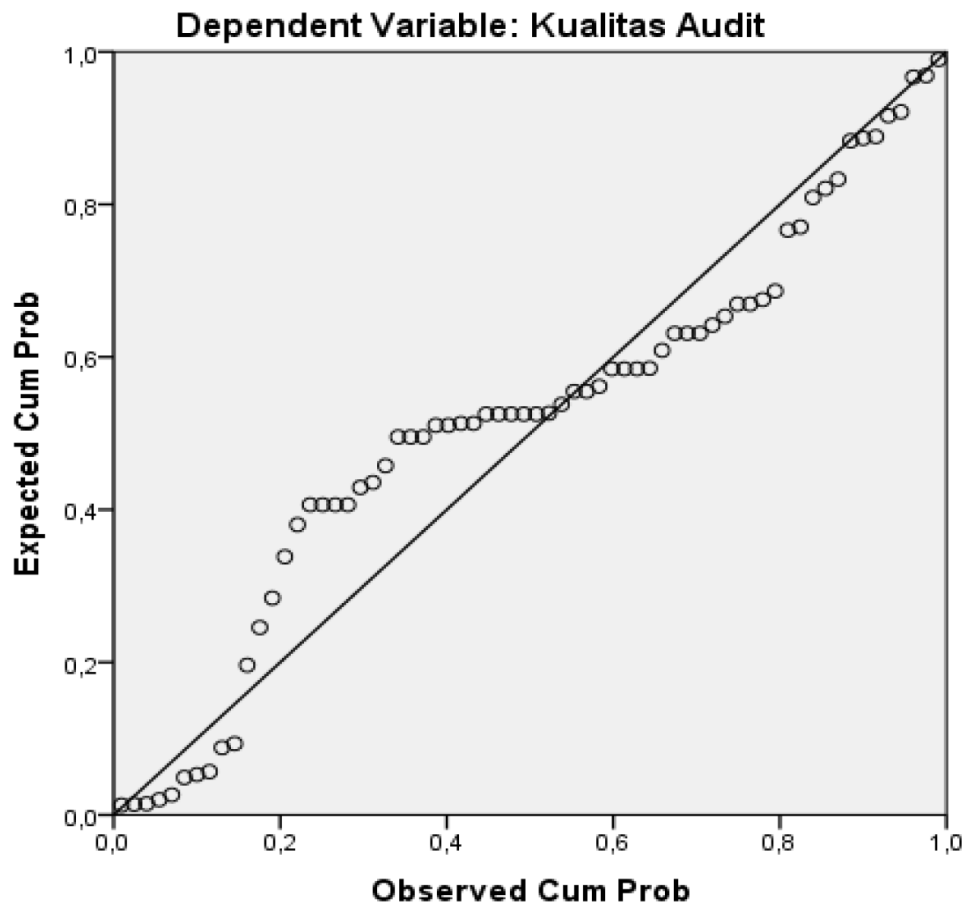

Sumber: Data Penelitian, 2020

Pada penelitian ini dalam menguji normalitas juga dilengkapi dengan uji statistik non-parametrik kolmogorov-smirnov. Jika hasilnya mempunyai nilai $P$-value $\geq 0,05$ maka dikatakan data normal. Berdasarkan hasil olah SPSS menunjukkan nilai kolmogorovsmirnov Z sebesar 1,788 dengan tingkat signifikan 0,063 hal ini menunjukkan bahwa variabel penelitian terdistribusi normal karena tingkat signifikasinya $\geq 0,05$. Pada model 2 nilai kolmogorov-smirnov Z sebesar 1,437 dengan tingkat signifikan 0,082 hal ini menunjukkan bahwa variabel penelitian terdistribusi normal karena tingkat signifikasinya $\geq 0,05$.

\section{Uji Multikolinieritas}

Hasil uji multikolinieritas disajikan pada tabel berikut:

Tabel 3 Hasil Uji Multikolinieritas

\begin{tabular}{llcc} 
& Model & \multicolumn{2}{c}{ Collinearity Statistics } \\
\cline { 3 - 4 } & & Tolerance & VIF \\
\hline 1 & Kompleksitas Tugas & 0,751 & 1,332 \\
& Disfungsional Auditor & 0,751 & 1,332 \\
\multicolumn{2}{l}{ Dependent Variable: Kualitas Audit } & & \\
\hline
\end{tabular}

Sumber: Data Penelitian, 2020 
Dari data pada tabel 3 dapat dilihat bahwa nilai tolerance seluruh variabel bebas di atas 0,1 dan nilai VIF di bawah 10. Hal ini menunjukkan data penelitian ini terbebas dari multikolinearitas.

\section{Uji Heteroskedastisitas}

Pengujian heteroskedatisitas dilakukan dengan melihat pola dan uji glejser. Yang pertama melihat pola, jika terdapat pola tertentu seperti titik-titk yang teratur maka mengidentifikasikan telah terjadi heteroskedastisitas. Namun jika pola seperti titik-titik yang menyebar pada sumbu Y, maka terbebas dari heteroskedastisitas. Gambar 3 berikut menunjukkan bahwa penelitian ini tidak mengalami heteroskedastisitas.

\section{Gambar 3 Hasil Uji Heteroskedastisitas}

\section{Scatterplot}

Dependent Variable: Kualitas Audit

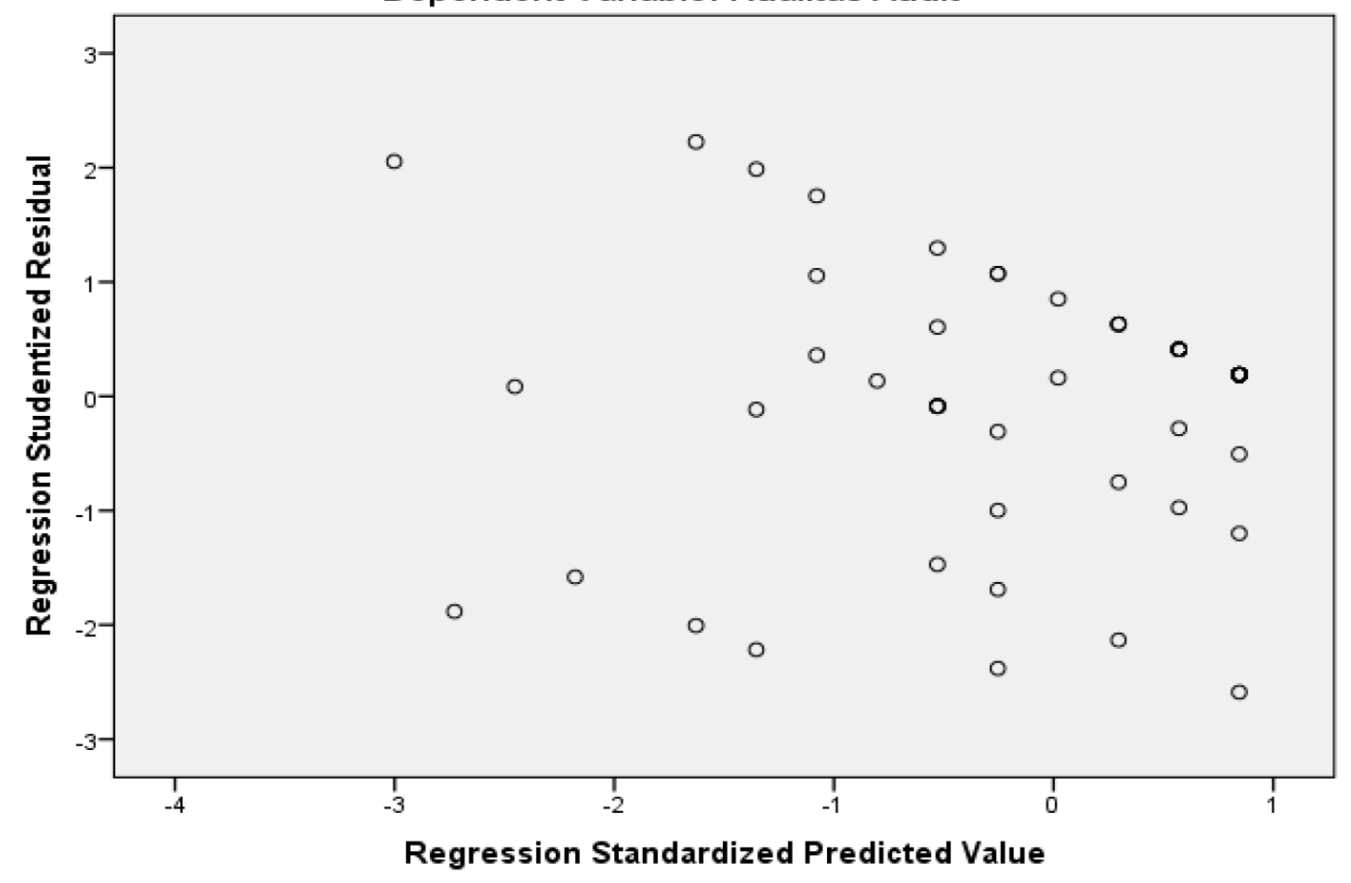

Sumber: Data Penelitian, 2020

Uji heteroskedastisitas kedua yaitu menggunakan alat statistik berupa uji glejser. Hasil uji glejser disajikan pada tabel berikut:

Tabel 4 Hasil Uji Heterokedastisitas

\begin{tabular}{cccc}
\hline & Model & t & Sig \\
\hline $1 \quad$ Kompleksitas Tugas & 3,683 & 0,065 \\
& Disfungsional Auditor & 1,534 & 0,130 \\
Dependent Variable: Kualitas Audit & & \\
\hline
\end{tabular}

Sumber: Data Penelitian, 2020 
Berdasarkan hasil uji yang ditunjukkan pada tabel 4 menunjukan bahwa variabel penelitian tidak terjadi heteroskedastisitas karena nilai signifikan menunjukkan nilai $\geq 0,05$

\section{Uji Hipotesis}

Pada penelitian ini, metode yang digunakan untuk menguji hipotesis adalah Moderated Regression Analysis (MRA):

$$
\begin{aligned}
& \mathrm{KA}=\alpha+\beta_{1} \mathrm{KT}+\varepsilon \\
& \mathrm{KA}=\alpha+\beta_{1} \mathrm{KT}+\beta_{2} \mathrm{DA}+\beta_{3} \mathrm{KTDA}+\varepsilon
\end{aligned}
$$

Keterangan:

$\mathrm{KA}=$ Kualitas Audit

$\alpha=$ Bilangan konstanta

$\beta=$ Koefisien arah persamaan penelitian

$\mathrm{KT}=$ Kompleksitas Tugas

DA = Disfungsional Auditor

$\varepsilon \quad=$ Error

Hasil pengujian hipotesis untuk model 1 disajikan pada tabel 5, sementara untuk model 2 disajikan pada tabel 6 berikut:

\begin{tabular}{|c|c|c|c|c|c|c|}
\hline & \multirow[t]{2}{*}{ Model } & \multicolumn{2}{|c|}{$\begin{array}{l}\text { Unstandardized } \\
\text { Coefficients }\end{array}$} & \multirow{2}{*}{$\begin{array}{c}\begin{array}{c}\text { Standardized } \\
\text { Coefficients }\end{array} \\
\text { Beta }\end{array}$} & \multirow[t]{2}{*}{$\mathbf{t}$} & \multirow[t]{2}{*}{ Sig. } \\
\hline & & B & Std. Error & & & \\
\hline \multirow[t]{2}{*}{1} & (Constant) & 26,009 & 0,395 & & 65,819 & 0,000 \\
\hline & Kompleksitas Tugas & $-0,320$ & 0,050 & $-0,627$ & $-6,440$ & 0,000 \\
\hline & ndent Variable: Kuali & & & & & \\
\hline
\end{tabular}

Tabel 5 Hasil Analisis Regresi Sederhana (Model 1)

Sumber: Data Penelitian, 2020

Berdasarkan data pada tabel 5, maka persamaan penelitian yang menunjukkan pengaruh kompleksitas tugas terhadap kualitas audit yang dapat dibentuk adalah:

$$
\text { Kualitas Audit }=26,009-0,320(\text { KT) }+\varepsilon
$$

Sementara itu, variabel kompleksitas tugas memiliki nilai $t$ sebesar $-6,440$ dengan signifikansi 0,000 $(<0,05)$. Nilai signifikan $<$ Alpha menunjukkan secara parsial variabel kompleksitas tugas berpengaruh pada kualitas audit. 
Tabel 6 Hasil Analisis MRA (Model 2)

\begin{tabular}{|c|c|c|c|c|c|c|}
\hline & \multirow[t]{2}{*}{ Model } & \multicolumn{2}{|c|}{$\begin{array}{l}\text { Unstandardized } \\
\text { Coefficients }\end{array}$} & \multirow{2}{*}{$\begin{array}{c}\begin{array}{c}\text { Standardized } \\
\text { Coefficients }\end{array} \\
\text { Beta }\end{array}$} & \multirow[t]{2}{*}{$\mathbf{t}$} & \multirow[t]{2}{*}{ Sig. } \\
\hline & & B & Std. Error & & & \\
\hline \multirow[t]{4}{*}{1} & (Constant) & 28,048 & 1,239 & & 22,630 & 0,000 \\
\hline & Kompleksitas Tugas & $-0,568$ & 0,196 & $-1,112$ & $-2,904$ & 0,005 \\
\hline & Disfungsional Auditor & $-0,196$ & 0,109 & $-0,400$ & $-1,797$ & 0,077 \\
\hline & Kompleksitas.Disfungsional & 0,022 & 0,15 & 0,742 & 1,480 & 0,144 \\
\hline \multicolumn{7}{|c|}{ Dependent Variable: Kualitas Audit } \\
\hline
\end{tabular}

Sumber: Data Penelitian, 2020

Tabel 6 memperlihatkan nilai koefisien regresi dari variabel independen setelah dimoderasi oleh variabel pemoderasi (Kompleksitas.Disfungsional), nilai konstanta variabel dependen, dan nilai signifikansi masing-masing variabel. Persamaan yang menunjukkan pengaruh kompleksitas tugas setelah dimoderasi oleh disfungsional auditor terhadap kualitas audit adalah:

$$
\text { Kualitas Audit }=28,048-0,568(\text { KT) }-0,196(D A)+0,022(\text { KTDA })+\varepsilon
$$

Selain itu, data pada tabel 6 menunjukkan nilai t variabel moderasi disfungsional auditor sebesar 1,480 dengan signifikansi 0,144 (>0,05). Nilai signifikan > Alpha menunjukkan variabel moderasi disfungsional auditor secara parsial tidak berpengaruh pada kompleksitas tugas terhadap kualitas audit.

\section{Uji Koefisien Determinasi (R2)}

Hasil uji koefisien determinasi (R2) untuk Model 1 ditampilkan di tabel 7, sedangkan hasil uji koefisien determinasi (R2) untuk Model 2 ditampilkan di tabel 8.

Tabel 7 Hasil Uji Koefisien Determinasi Model 1

\begin{tabular}{ccccc}
\hline Model & $\mathbf{R}$ & R Square & Adjusted R Square & Std. Error of the Estimate \\
\hline 1 & $0,627^{\text {a }}$ & 0,393 & 0,384 & 1,45931 \\
a. Predictors: (Constant), Kompleksitas Tugas & & \\
\hline
\end{tabular}

Sumber: Data Penelitian, 2020

Tabel 7 menunjukkan nilai Adjusted $R$ Square sebesar 0,384 atau 38,4\%. Artinya, variasi variabel independen kompleksitas tugas yang diuji dalam penelitian ini mampu menjelaskan variasi perubahan variabel dependen kualitas audit sebesar 38,4\%. Sisanya sebesar $61,6 \%$ dipengaruhi oleh faktor lain di luar model penelitian. 
Tabel 8 Hasil Uji Koefisien Determinasi Model 2

\begin{tabular}{ccccc}
\hline Model & $\mathbf{R}$ & R Square & Adjusted R Square & Std. Error of the Estimate \\
\hline 1 & $0,651^{\text {a }}$ & 0,423 & 0,396 & 1,44523 \\
a. Predictors: (Constant), KTDA, DA, Kompleksitas Tugas & \\
\hline
\end{tabular}

Sumber: Data Penelitian, 2020

Tabel 8 memperlihatkan nilai Adjusted $R$ Square sebesar 0,396. Artinya, dalam penelitian ini variasi variabel independen setelah dimoderasi oleh variabel pemoderasi disfungsional auditor mampu menjelaskan variasi perubahan variabel dependen sebesar $39,6 \%$. Sementara sisanya, 60,4\% dipengaruhi oleh variabel lain di luar model penelitian. Hal tersebut juga mengindikasikan adanya peningkatan variasi perubahan kompleksitas tugas dalam menjelaskan variasi perubahan kualitas audit setelah dimoderasi oleh disfungsional auditor.

\section{Uji F}

Hasil uji F disajikan pada tabel berikut:

Tabel 9 Hasil Uji F

\begin{tabular}{llccccc}
\hline & Model & Sum of Squares & Df & Mean Square & F & Sig. \\
\hline 1 & Regression & 95,122 & 3 & 31,707 & 15,180 & $0,000^{\mathrm{b}}$ \\
\cline { 3 - 5 } & Residual & 129,500 & 62 & 2,089 & & \\
Total & 224,621 & 65 & & &
\end{tabular}

a. Dependent Variable: Kualitas Audit

b. Predictors: (Constant), KTDA, Disfungsional Auditor, Kompleksitas Tugas

Sumber: Data Penelitian, 2020

Dalam penelitian ini untuk menguji nilai statistik tabel F-tabel menggunakan F-tabel $=\mathrm{F}(\alpha ; \mathrm{dfn} / \mathrm{dfd}) \alpha$. Dari data pada tabel 9, nilai $\mathrm{df}$ atas $=\mathrm{dfn}=3$ dan $\mathrm{df}$ bawah $=\mathrm{dfd}=$ 62. Oleh karena itu, besarnya Ftabel $=F(\alpha ; d f n / d f d)$ yang dicari adalah $F(0,05 ; 3 / 62)$ yang menunjukkan nilai 2,75. Besarnya Fhitung $=15,180$ dengan nilai Sig.hitung $=0,000$.

\section{Pengaruh Kompleksitas Tugas terhadap Kualitas Audit}

Hipotesis pertama yang diuji menggunakan model regresi linier dalam penelitian ini dinyatakan diterima dengan nilai signifikansi sebesar 0,000, yang artinya, bahwa kompleksitas tugas berpengaruh positif terhadap kualitas audit. Hal ini menunjukkan bahwa semakin kompleks beban kerja auditor, semakin dapat menekan auditor untuk melakukan tindakan yang mungkin berdampak terhadap proses audit. Padahal, hasil akhir pekerjaan audit sangat bergantung pada proses audit tersebut. 
Selama kegiatan audit berlangsung, hanya auditor yang bersangkutan dengan klien yang mengetahui apakah hasil pekerjaan yang dilakukan telah sesuai dengan prosedur atau ada yang sengaja dihilangkan maupun diganti. Jika ternyata tidak sesuai prosedur, sudah dapat dipastikan bahwa kualitas laporan audit yang dihasilkan sangat buruk. Auditor yang memiliki beban kerja mental yang berat dapat berpengaruh terhadap keputusan yang diambil (Benford, 2000).

Penelitian ini sejalan dengan yang dilakukan oleh Jelista (2015) serta Prasita \& Priyo (2007) suatu tugas yang diberikan kepada individu yang tidak mampu bekerja dengan bobot pekerjaan yang kompleks akan semakin menurunkan tingkat keberhasilan. Hasil penelitian ini tidak konsisten dengan penelitian yang dilakukan oleh Purnamasari \& Merkusiswati (2017) serta Setyorini \& Dewayanto (2011) yang menyatakan bahwa setiap perikatan yang hendak dilakukan, Kantor Akuntan Publik akan memilih auditor yang tepat, yang mampu secara kompetensi dan keahlian.

\section{Disfungsional Auditor memoderasi pengaruh Kompleksitas Tugas terhadap Kualitas Audit}

Hasil pengujian statistik menunjukkan nilai signifikansi sebesar 0,144 yang berarti hipotesis kedua kompleksitas tugas dan disfungional auditor sebagai pemoderasi tidak berpengaruh secara signifikan atau negatif terhadap kualitas audit. Hasil penelitian ini mendukung hasil penelitian yang dilakukan oleh Yuen, Desmond, Law, \& JieQi (2012) yang menyatakan ketidakkedukungannya terhadap teori perubahan sikap khususnya dissonance theory. Teori ini menjelaskan hubungan ketidaksesuaian yang membuat seseorang termotivasi untuk menghilangkan ketidaksesuaian tersebut.

Hasil penelitian ini bertolak belakang dengan penelitian Dewi \& Wirasedana (2015), Shauki, Umar, \& Diyanti (2017) dan Rohman (2018). Semakin kompleks beban pekerjaan yang dihadapi seseorang, maka ia akan berupaya untuk mengeliminasi atau membuat skala prioritas dan menghilangkan sesuatu yang dianggap tidak begitu penting. Sehingga, akan sangat berdampak terhadap pengambilan keputusan karena berupaya untuk menyederhanakan teknik.

\section{SIMPULAN}

Dari penelitian yang telah dilakukan, dapat disimpulkan bahwa variabel independen kompleksitas tugas berpengaruh terhadap kualitas audit. Disfungsional auditor tidak mampu memoderasi kompleksitas tugas terhadap kualitas audit. Diharapkan dengan adanya penelitian ini dapat memberikan tambahan wawasan bagi auditor tentang implikasi yang mempengaruhi kualitas audit.

\section{PUSTAKA ACUAN}

Benford, T. (2000). Determinants of Audit Performance: An Investigation of Task/ Technology Fit and Mental Workload. Dissertation Abstracts International, Vol. 61-08 pp. 32-41. 
De Angelio, L. E. (1981). Auidtor Size and Auditor Quality. Journal of Accounting and Economics, 183-199.

Dewi, N., \& Wirasedana, I. (2015). Pengaruh Time Budget Pressure, Locus of Control, and Task Complexity pada Dysfunctional Audit Behavior Akuntan Publik. E-Jurnal Akuntansi Universitas Udayana, Vol. 11 No.1 pp. 1-14.

Donnely, D., Jeffrey, J., \& David, O. (2003). Auditor Acceptance of Dysfunctional Audit Behavior : An Explanatory Model Using Auditors' Personal Characteristics. Journal of behavioral Research In Accounting, Vol. 15:87-107.

Jelista, M. (2015). Pengaruh Kompleksitas Audit, Tekanan Anggaran Waktu, Dan Pengalaman Auditor Terhadap Kualitas Audit Dengan Variabel Moderating Sitem Iinformasi (Studi Empiris pada Kantor Akuntan Publik di Pekanbaru, Medan dan Padang). Jom FEKON, Vol. 2. No. 2.

Kelley, T., \& Margheim, L. (1990). The Impact of Time Budget Pressure, Personality and Leadership Variabel on Dysfunctional Behavior. Auditing: A Journal of Practice and Theory, Vol 9. No. 2 pp. 21-41.

Prasita, A., \& Priyo, H. (2007). Pengaruh Kompleksitas Audit dan Tekanan Anggaran Waktu terhadap Kualitas Audit dengan Moderasi Pemahaman terhadap Sistem Informasi. Journal of Economics and Business Fakultas Ekonomi: Universitas Kristen Satya Wacana, Vol. VIII, No. 1.

Purnamasari, P., \& Merkusiwati, N. (2017). Pengaruh Kompleksitas Tugas, Independensi, dan Kompetensi Terhadap Kualitas Audit dengan Integritas Auditor sebagai Variabel Pemoderasi. E-Jurnal Akuntansi Univeristas Udayana, Vol. 19. No. 3.

Risma, D. (2019). Pengaruh Kompetensi, Independensi, Time Budget Pressure, dan Audit Fee terhadap Kualitas Audit pada Kantor Akuntan Publik di Kota Medan. Medan: Fakultas Ekonomi dan Bisnis Universitas Muhammadiyah Sumatera Utara.

Rohman, A. (2018). Pengaruh Kompleksitas Tugas, Tekanan Anggaran Waktu, dan Independensi Auditor terhadap Perilaku Disfungsional Auditor dan Implikasinya terhadap Kualitas Audit. Jurnal Riset Akuntansi Tirtayasa, Vol. 03 No. 02. ISSN: 25487078.

Sanjaya, I. W., \& Suputra, I. G. (2019). Peran Karakteristik Personal Auditor Memoderasi Pengaruh Time Budget Presure terhadap Perilaku Disfungsional Auditor. e-Jurnal Akuntansi, Vol. 29 No. 2 e-ISSN 2302-8556.

Setyorini, A., \& Dewayanto, T. (2011). Pengaruh Kompleksitas Audit, Tekanan Anggaran Waktu, dan Pengalaman Auditor Terhadap Kualitas Audit dengan Variabel Moderating Pemahaman Terhadap Sistem Informasi (Studi Empiris pada Auditor KAP di Semarang). Jurnal Ekonomi Universitas Diponegoro .

Shauki, E., Umar, M., \& Diyanti, V. (2017). Pressure, Dysfuctional Behavior, Fraud Detection and Role of Information Technology in The Audit Process. Australasian Accounting, Business and Finance Journal, Vol. 11 Issue 4, 102-115.

Sugiyono. (2011). Metode Penelitian Kuantitatif, Kualitatif, dan $R \& D$. Bandung: Alfabeta. 
Wood, R. E. (1986). Task Complexity. Definition of The Construct. Organizational Behaviour and Human Decision Process, 60-82.

www.iapior.id. (2020).

Yuen, P., Desmond, C., Law, C., \& JieQi, G. (2012). Dysfunctional Auditing Behaviour: Empirical Evidence on Auditors Behaviour in Macau. International Journal of Accounting and Information Management, Vol. 4, No. 5. pp. 1-20. 